\title{
Suppression of BRD4 inhibits human hepatocellular carcinoma by repressing MYC and enhancing BIM expression
}

\author{
Gong-Quan Li1,2,*, Wen-Zhi Guo ${ }^{1, *}$, Yi Zhang ${ }^{3,4}$, Jing-Jing Seng ${ }^{5}$, Hua-Peng Zhang ${ }^{2}$, \\ Xiu-Xian Ma ${ }^{1}$, Gong Zhang ${ }^{1}$, Jie Li ${ }^{1}$, Bing Yan ${ }^{2}$, Hong-Wei Tang ${ }^{2}$, Shan-Shan Li ${ }^{6}$, Li- \\ Dong Wang ${ }^{7}$ and Shui-Jun Zhang ${ }^{1,2}$ \\ ${ }^{1}$ Department of Hepatobiliary and Pancreatic Surgery, The First Affiliated Hospital of Zhengzhou University, Zhengzhou, \\ Henan, China \\ ${ }^{2}$ Open and Key Laboratory of Hepatobiliary and Pancreatic Surgery and Digestive Organ Transplantation at Henan Universities, \\ The First Affiliated Hospital of Zhengzhou University, Zhengzhou, Henan, China \\ ${ }^{3}$ Department of Orthopaedic Surgery, The First Affiliated Hospital of Zhengzhou University, Zhengzhou, Henan, China \\ ${ }^{4}$ The Hormel Institute, University of Minnesota, Minneapolis, MN, USA \\ ${ }^{5}$ Department of Pathology, Brigham and Women's Hospital, Harvard Medical School, Boston, MA, USA \\ ${ }^{6}$ Department of Pathology, The First Affiliated Hospital of Zhengzhou University, Zhengzhou, Henan, China \\ ${ }^{7}$ Henan Key Laboratory for Esophageal Cancer Research, The First Affiliated Hospital of Zhengzhou University, Zhengzhou, \\ Henan, China \\ * These authors have contributed equally to this work
}

Correspondence to: Shui-Jun Zhang, email: zhangshuijun2007@163.com

Keywords: HCC, JQ1, BRD4, BIM, MYC

Received: June 29, $2015 \quad$ Accepted: October 01, $2015 \quad$ Published: November 12, 2015

This is an open-access article distributed under the terms of the Creative Commons Attribution License, which permits unrestricted use, distribution, and reproduction in any medium, provided the original author and source are credited.

\section{ABSTRACT}

Bromodomain 4 (BRD4) is an epigenetic regulator that, when inhibited, has anti-cancer effects. In this study, we investigated whether BRD4 could be a target for treatment of human hepatocellular carcinoma (HCC). We show that BRD4 is overexpressed in HCC tissues. Suppression of BRD4, either by siRNA or using JQ1, a pharmaceutical BRD4 inhibitor, reduced cell growth and induced apoptosis in HCC cell lines while also slowing HCC xenograft tumor growth in mice. JQ1 treatment induced G1 cell cycle arrest by repressing MYC expression, which led to the up-regulation of CDKN1B (P27). JQ1 also de-repressed expression of the pro-apoptotic BCL2L11 (BIM). Moreover, siRNA knockdown of BIM attenuated JQ1-triggered apoptosis in HCC cells, suggesting an essential role for BIM in mediating JQ1 anti-HCC activity.

\section{INTRODUCTION}

Hepatocellular carcinoma (HCC) is one of the most common solid tumors and a leading cause of cancerrelated death worldwide [1]. Bromodomain 4 (BRD4) is a member of the bromodomain and extra-terminal (BET) family of proteins [2] which acts as a transcriptional coactivator by facilitating the recruitment of the positive transcription elongation factor P-TEFb [3, 4]. Aberrant BRD4 expression may promote tumorigenesis in multiple myeloma (MM), leukemia and several types of solid cancers via transcriptional activation of oncogenic drivers. Accordingly, there has been much effort to target BRD4 using pharmaceutical inhibitors [3-10].
JQ1 is a small molecule inhibitor of BET proteins with high binding affinity for BRD4 [3]. JQ1 and BRD4 competitively bind to chromatin at gene enhancers, and JQ1 suppresses the expression of oncogenic proteins such as c-Myc [3-10]. Preclinical studies of JQ1 as a treatment for hematological malignancies and solid tumors have demonstrated its anti-cancer activity, largely through the suppression of c-Myc [7-13]. HCC tumors express high levels of c-Myc, and increased c-Myc expression correlates with a more advanced and aggressive phenotype; thus, inhibition of c-Myc has long been proposed as a treatment of HCC [14-20]. In fact, a recent study by Puissant and colleagues reported that several HCC cell lines were sensitive to JQ1 [21]. 
In this study, we hypothesized that BRD4 inhibitors would act as anti-cancer agents in HCC via c-Myc suppression. To test that idea, we investigated the role of BRD4 in HCC and the anti-cancer effects of BRD4 inhibitors in HCC. We found that BRD4 is overexpressed in HCC tissues and that inhibition of BRD4 by JQ1 suppresses cell proliferation by blocking cell cycle progression and inducing apoptosis in HCC cells.

A
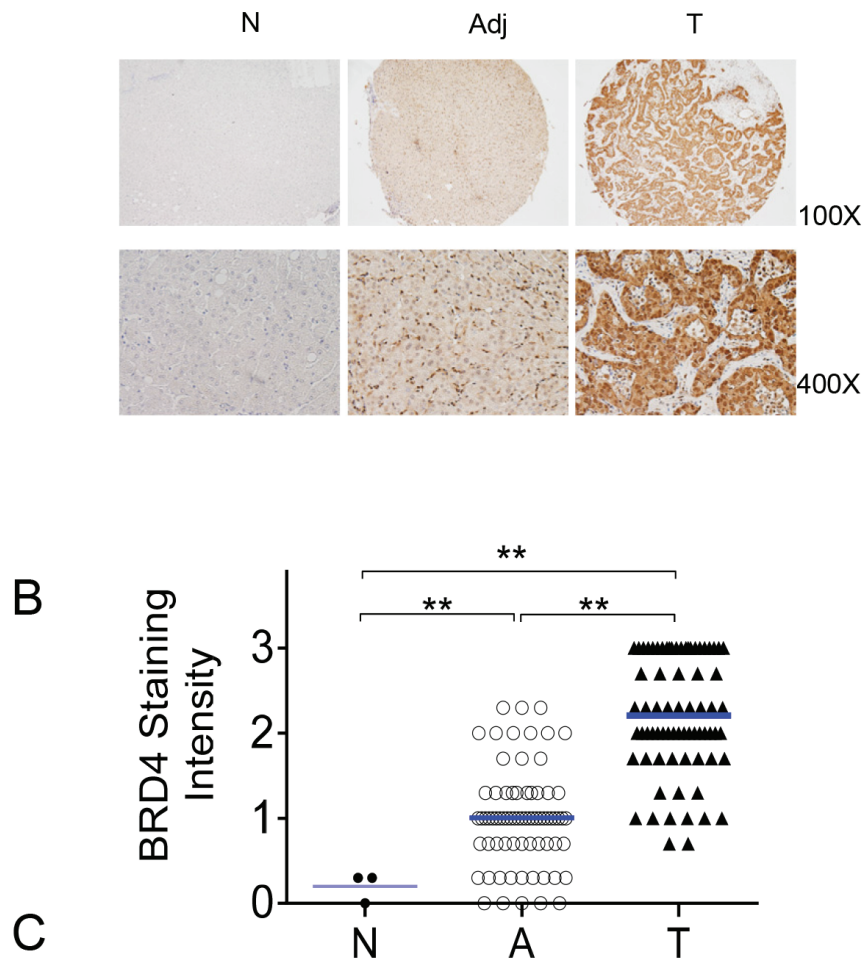

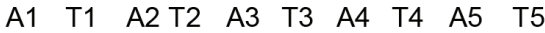

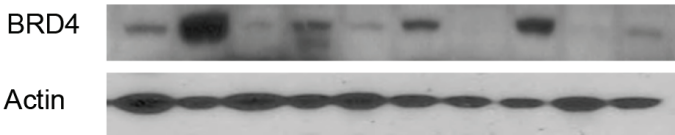

\section{RESULTS}

\section{BRD4 is over-expressed in $\mathrm{HCC}$ cells and tumor tissues}

We first evaluated BRD4 expression using immunohistochemical (IHC) staining in tissue arrays containing HCC tumors and corresponding adjacent non-neoplastic liver tissues from 72 patients. Normal

D

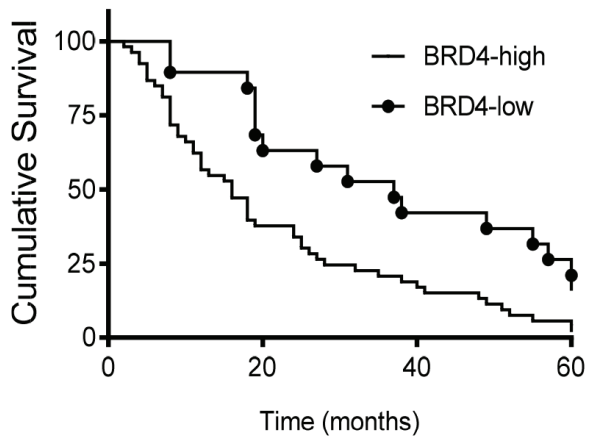

$E$

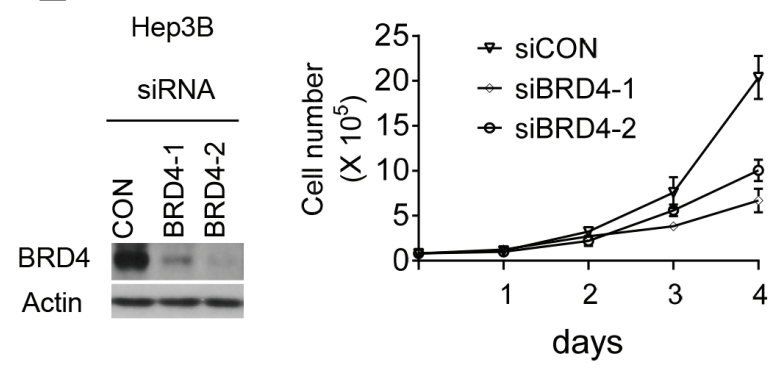

$\mathrm{F}$

HCCLM3

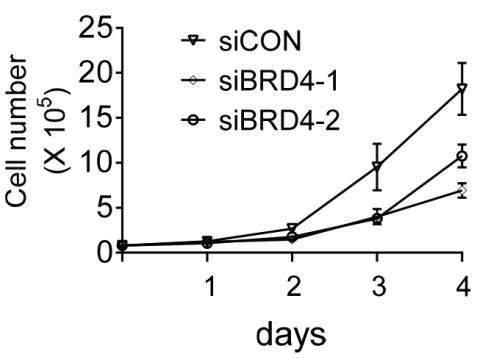

Figure 1: BRD4 is overexpressed in HCC and drives HCC cell growth. A.-D. BRD4 expression was analyzed by IHC in human liver tissues. A. Representative BRD4 staining of de-paraffinized sections of normal liver (N), adjacent liver (Adj) and HCC tumor (T) tissues. B. Intensity levels of BRD4 expression are shown for 72 cases of paired adjacent liver and HCC tumor tissues, as well as in normal liver tissues (t-test, A vs. N, $* * p<0.01$, T vs. $\mathrm{N},{ }^{*} p<0.01$, T vs. A, $* * p<0.001$ ). C. Western blot analysis of BRD4 in HCC tumor tissues (T1-5) and adjacent liver tissues (A1-5). Actin was used as a loading control. D. Kaplan-Meier curves for the overall survival rate of patients with HCC according to BRD4 expression $(p<0.01$, hazard ratio $[\mathrm{HR}]=2.18,95 \%$ confidence interval $[\mathrm{CI}]=1.32$ to 3.6$)$. E., F. HCC cell lines Hep3B and HCCLM3 were transfected with two independent BRD4 siRNAs (siBRD4-1, siBRD4-2) or control siRNA ( $\mathrm{siCON}$ ), and the efficiency of BRD4 knockdown was assessed by western blotting analysis $24 \mathrm{~h}$ after transfection. Actin was used as a loading control (left panels). The numbers of the transfected cells were measured daily by manual counting for a period of 6 days following transfection (right panels). 
human liver tissues from three healthy donors were used as controls. BRD4 was weakly expressed in normal liver tissues and highly expressed in both primary tumor and adjacent liver tissues (Figure 1A). However, tumor tissues were stained more intensely than the non-neoplastic liver tissues ( $p<0.01$; Figure 1A, 1B and Figure S1A, S1B). Western blots of 5 pairs of tumors/adjacent liver tissues confirmed increased expression of BRD4 in HCC tumors (Figure 1C). BRD4 expression in $\mathrm{HCC}$ tumor tissues differed by and was positively correlated with American Joint Committee on Cancer (AJCC) cancer stage, with mean scores of $1.7 \pm 0.2,2.1 \pm 0.1,2.5 \pm 0.1$ and $2.6 \pm$ 0.2 for stage I, II, III and IV samples, respectively (oneway ANOVA, $p<0.05$, Spearman, $p<0.05$; Figure S1A, Figure S1B, and Table S1). In addition, HCC patients with higher BRD4 expression had lower survival rates than patients with lower BRD4 expression (log-rank test, hazard ratio $[\mathrm{HR}]=2.18,95 \%$ confidence interval $[\mathrm{CI}]=$ 1.32 to $3.6, p<0.001$; Figure $1 \mathrm{D})$. These results suggest that BRD4 expression is increased with $\mathrm{HCC}$ disease progression.

A

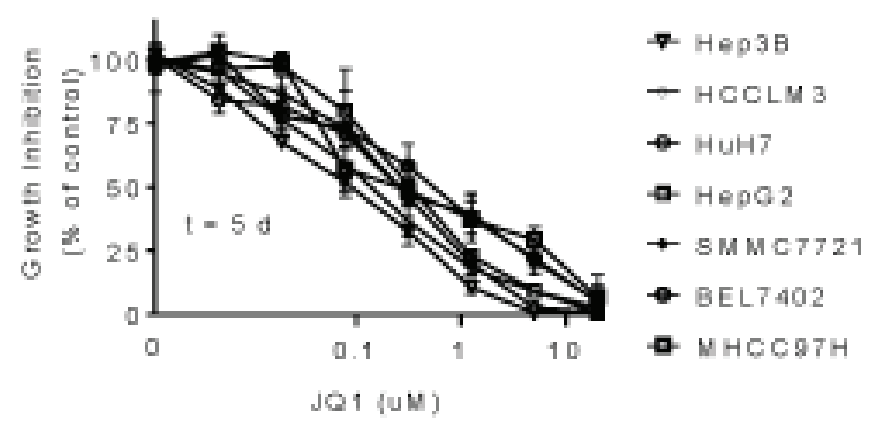

\begin{tabular}{|l|l|}
\hline Cell line & IC50( $\mu \mathrm{M})$ \\
\hline Hep3B & 0.08 \\
\hline HCCLM3 & 0.14 \\
\hline HuH7 & 0.21 \\
\hline HepG2 & 0.34 \\
\hline SMMC7721 & 0.41 \\
\hline BEL7402 & 0.47 \\
\hline MHCC97H & 0.41 \\
\hline
\end{tabular}
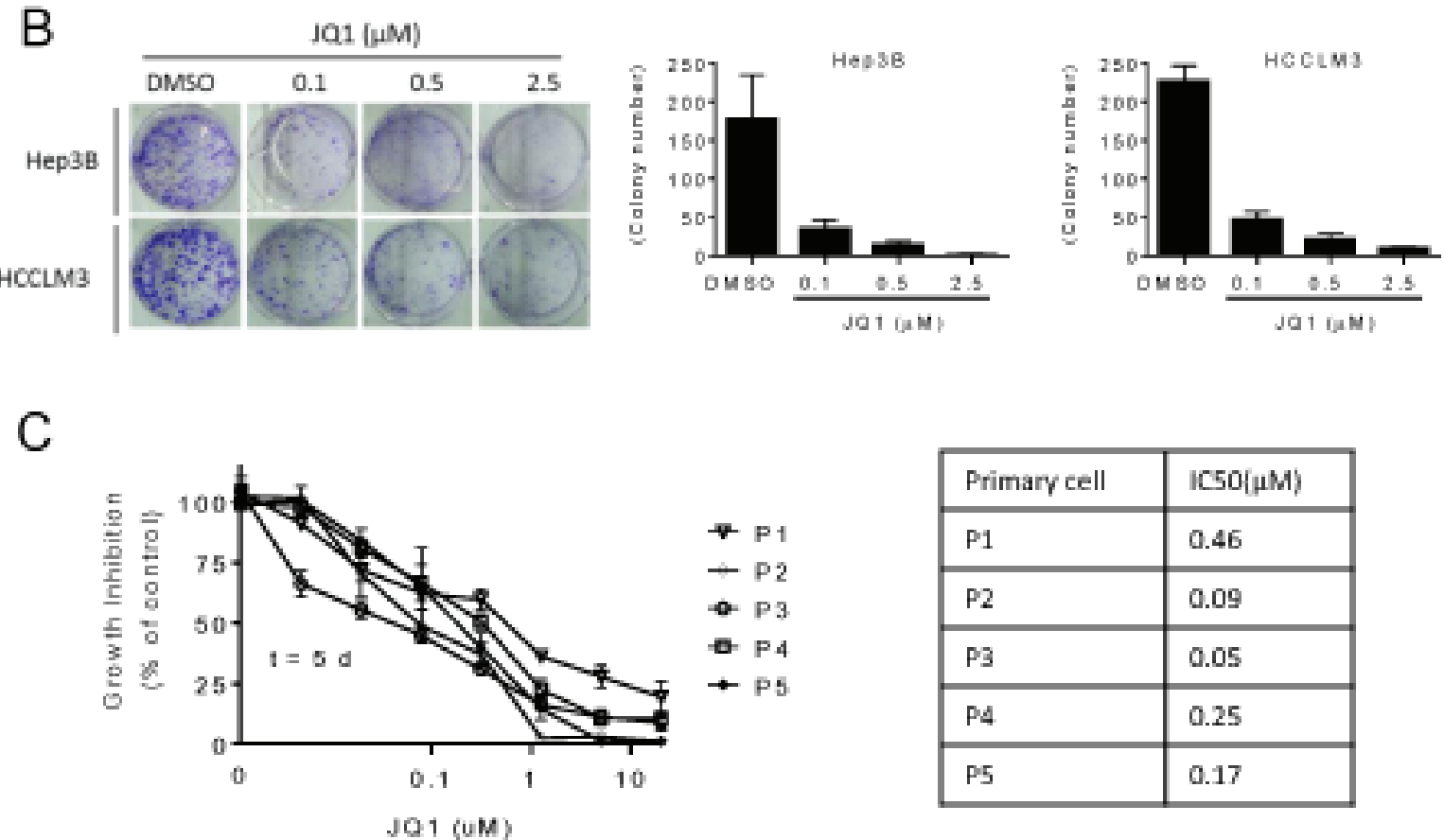

\begin{tabular}{|c|c|}
\hline Primary cell & IC50 $\{\mu \mathrm{M})$ \\
\hline P1 & 0.46 \\
\hline $\mathrm{P} 2$ & 0.09 \\
\hline P3 & 0.05 \\
\hline P4 & 0.25 \\
\hline P5 & 0.17 \\
\hline
\end{tabular}

Figure 2: JQ1 inhibits human HCC cell proliferation. A. Human HCC cell lines were treated with serial dilutions of JQ1 for 5 days and cell growth was determined using an MTT assay. The dose-response growth curves (left panel) and IC50 values of JQ1 (right panel) were obtained for each cell line. B. Hep3B and HCCLM3 cell lines were seeded into six-well plates at 1,000 cells per well in triplicates and treated with JQ1 for 2 weeks, followed by $0.01 \%(\mathrm{w} / \mathrm{v})$ crystal violet staining and colony counting. Representative images are shown for colony formation for Hep3B and HCCLM3 cell lines (left panels). The data depict the mean \pm S.D of clone numbers (right panels). C. Primary HCC cells were treated with JQ1 as described in (A), and the dose-response growth curves (left panel) and IC50 values of JQ1 (right panel) were obtained for each cell line. 


\section{BRD4 expression stimulates HCC cell growth}

To investigate the role of BRD4 in $\mathrm{HCC}$ cell growth, using two different siRNAs we suppressed $B R D 4$ expression in Hep3B and HCCLM3 cells and examined cell proliferation. Western blots showed that, in both cell lines, transfection of either siRNA for $24 \mathrm{~h}$ led to an almost complete suppression of $B R D 4$ activation compared with a non-targeting control siRNA (siCON; Figure 1E and $1 \mathrm{~F})$. Cells transfected with siCON grew rapidly, whereas cells transfected with BRD4 siRNA had inhibition of cell growth, particularly 4 days post-transfection. These results suggest that BRD4 is essential for HCC cell growth.

\section{JQ1 reduces human HCC cell proliferation}

Sensitivity to JQ1was evaluated across $7 \mathrm{HCC}$ cell lines by treating cells with serial dilutions of the drug for 5 days and then analyzing cell growth by MTT assays. JQ1 inhibited cell growth in a dose-dependent manner in all 7 HCC cell lines (Figure 2A). Hep3B and HCCLM3 were the most sensitive cell lines with IC50 values of 0.08 and $0.14 \mu \mathrm{M}$, respectively (Figure 2A; right panel). Notably, a 5- $\mu \mathrm{M}$ concentration of JQ1 was sufficient to completely inhibit cell growth in these two lines; therefore, they were chosen for subsequent experiments.

We next performed clonogenic assays to determine the long-term anti-proliferative effects of JQ1. JQ1 treatment for 14 days inhibited clone formation in a dosedependent manner in both cell lines (Figure 2B). Low doses of JQ1 $(0.1 \mu \mathrm{M})$ reduced clone numbers, while 2.5 $\mu \mathrm{M}$ JQ1 led to an almost complete inhibition of clone formation.

Finally, we examined the inhibitory effect of JQ1 in 5 primary HCC cells freshly isolated from surgically resected tumor tissues. MTT assays revealed that JQ1 treatment for 5 days inhibited primary HCC cell growth in all 5 cases (Figure 2C), with IC50 values observed between 0.05 and $0.5 \mu \mathrm{M}$. Together, our results demonstrate that JQ1 reduces proliferation in human HCCs.

\section{JQ1 induces cell cycle arrest and apoptosis in HCC cells}

To investigate the mechanism underlying the antiproliferative effects of JQ1 in HCC cells, we analyzed cell cycle distribution using flow cytometry. JQ1 treatment for $48 \mathrm{~h}$ led to an increased percentage of HCC cells in G1 phase arrest and a decrease in the percentage of cells in S phase (Figure 3A and 3B). JQ1 treatment also led to a substantial accumulation of HCC cells in sub-G1 phase (Figure 3C) and induced morphological changes characteristic of apoptosis, such as shrinkage, rounding, and floating. These changes became more prominent over time, particularly in Hep3B and HuH7 cells.

Next, we analyzed apoptotic-signaling pathways with cell fractionation and western blotting. JQ1 activated caspase- 3 and caspase- 9 expression and induced PARP cleavage as well as cytochrome c release into the cytoplasm from mitochondria (Figure 3D and 3E). Caspase-8 expression was not induced by JQ1 (data not shown), indicating that the mitochondrial apoptosis pathway, rather than the extrinsic pathway, mediates the anti-cancer activity of JQ1 in HCC cells. To determine whether caspase-9 was required for JQ1-induced anticancer activity, HCCLM3 and Hep3B cell lines were pre-treated with $50 \mu \mathrm{M}$ Z-LEHD-FMK, a pharmacological caspase-9 inhibitor for $1 \mathrm{~h}$ prior to the addition of JQ1 $(2.5 \mu \mathrm{M})$ for 3 days (Figure S2). Inhibition of caspase-9 activity reduced JQ1 induction of cell death, suggesting that the caspase- 9 initiated mitochondrial apoptosis pathway is essential for JQ1 activity in HCC cells.

\section{JQ1 represses $M Y C$ expression and increases p27 expression in $\mathrm{HCC}$ cells}

Building on previous studies which suggested that c-Myc is the critical mediator of JQ1's anti-cancer effects, we next used qRT-PCR and western blots to examine whether JQ1 treatment inhibited c-Myc expression in HCC cells. Indeed, JQ1 inhibited the expression of $M Y C$ in a time-dependent fashion (Figure 4A). siRNA knockdown of BRD4 also inhibited MYC transcription, suggesting that JQ1 reduced $M Y C$ through inhibition of BRD4 (Figure S3). To determine whether BRD4 binds directly to the $M Y C$ gene, we performed a chromatin immunoprecipitation (ChIP) experiment. BRD4 was enriched at the MYC enhancer in both HCC cell lines, but this association was reduced after 24 hours of JQ1 treatment (Figure 4B). These results suggest that JQ1 suppresses MYC transcription by reducing BRD4 binding to the $M Y C$ enhancer. Western blots confirmed that transcriptional repression of $M Y C$ by JQ1 led to time- and concentration-dependent decreases in c-Myc protein levels in both cell lines (Figure 4C and 4D).

Next, using siRNA to $M Y C$ in $\mathrm{HCC}$ cell lines we assessed the effects of this inhibition on cell growth (Figure 4E, 4F and Figure S4). MYC knockdown inhibited HCC cell growth; however, the effect was weaker than that triggered by JQ1 treatment at $2.5 \mu \mathrm{M}$, suggesting that JQ1 may have other functions besides inhibition of c-Myc. Previous studies had reported that JQ1 altered p27 and p21 expression $(22,24)$; therefore, we investigated the effects of JQ1 on the levels of p27 and p21 in HCC cell lines. We found that JQ1 led to increased p27 expression, but had a strong inhibitory effect on the expression of $\mathrm{p} 21$ in both HCC cell lines (Figure 4C and Figure S5). 

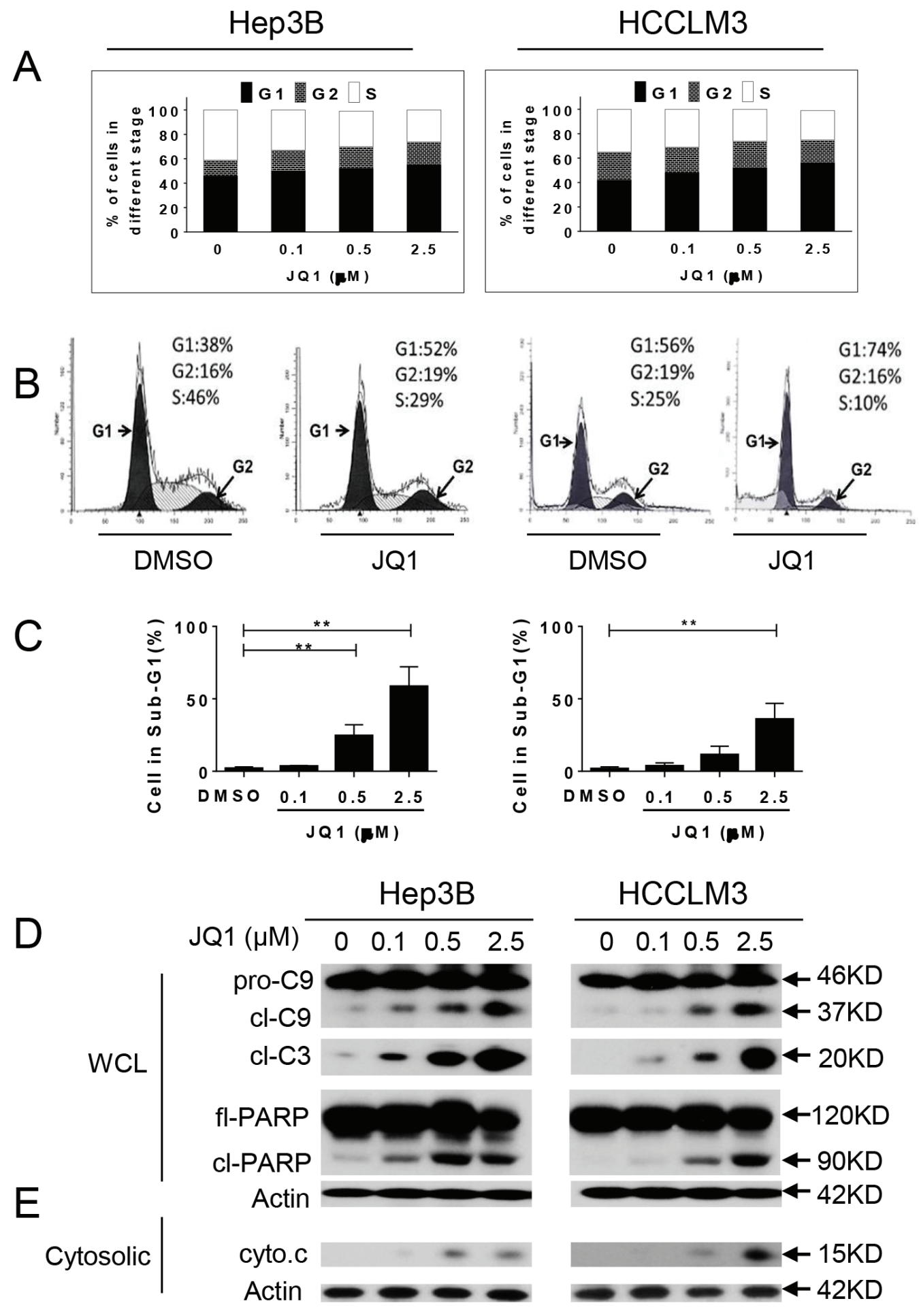

Figure 3: JQ1 arrests cell cycle in the G1 phase and induces apoptosis in HCC cells. A.-C. Hep3B and HCCLM3 cell lines were treated with JQ1 for $48 \mathrm{~h}$, stained with PI and examined with flow cytometry assays. A. The fractions of cells in each phase of the cell cycle are shown for the Hep3B and HCCLM3 cell lines. B. Representative plots of the cell cycle phases are shown for Hep3B and HCCLM3 cell lines treated with $0.5 \mu \mathrm{M}$ JQ1. C. The percentage of cells in the subG1 phase is shown for Hep3B and HCCLM3 cell lines. D.-E. Hep3B and HCCLM3 cells were treated with JQ1 for $48 \mathrm{~h}$. D. Hep3B (left panel) and HCCLM3 (right panel) cell lines were treated with JQ1 for $48 \mathrm{~h}$, whole cell lysates were analyzed by western blotting for the expression of pro-caspase-9 (pro-C9), cleaved-caspase-9 (cl-C9), cleaved-caspase-3 (cl-C3), full-length PARP (fl-PARP) and cleaved PARP (cl-PARP). Actin was used as a loading control. E. Hep3B (left panel) and HCCLM3 (right panel) cell lines were treated with JQ1 for $48 \mathrm{~h}$, treated cells were fractionated, and the expression of cytochrome c (cyto.c) in the cytosolic compartment was examined by western blotting. Actin was used as a loading control. 


\section{$\mathrm{BIM}$ is required for $\mathrm{JQ1}$-induced anti-cancer effects in $\mathrm{HCC}$ cells}

To unravel the discrepancy in the severity of anticancer effects observed between HCC cells treated with c-Myc siRNA or JQ1 (Figure 4E and 4F), we performed RNA-Seq analysis in HCCLM3 cells treated with or without $0.5 \mu \mathrm{M}$ JQ1 for $4 \mathrm{~h}$. Acute JQ1 treatment led to changes in the expression of a large number of genes, and the complete results are provided online (Supporting
Information). A heat map depicting the top 46 genes that were altered post-JQ1 treatment revealed enrichment for genes involved in the cell cycle and/or apoptosis (Figure $5 \mathrm{~A}$ ). As expected, $M Y C$ was among the genes inhibited by JQ1 treatment. In addition, the pro-apoptotic gene $B C L 2 L 11$ (BIM) was increased more than 2-fold after acute JQ1 treatment (Figure 5A and Supporting Information), a finding that was confirmed by qRT-PCR. Peak levels of $B I M$ mRNA were observed after $6 \mathrm{~h}$ of JQ1 treatment and were sustained for at least $48 \mathrm{~h}$ in both cell lines (Figure
A
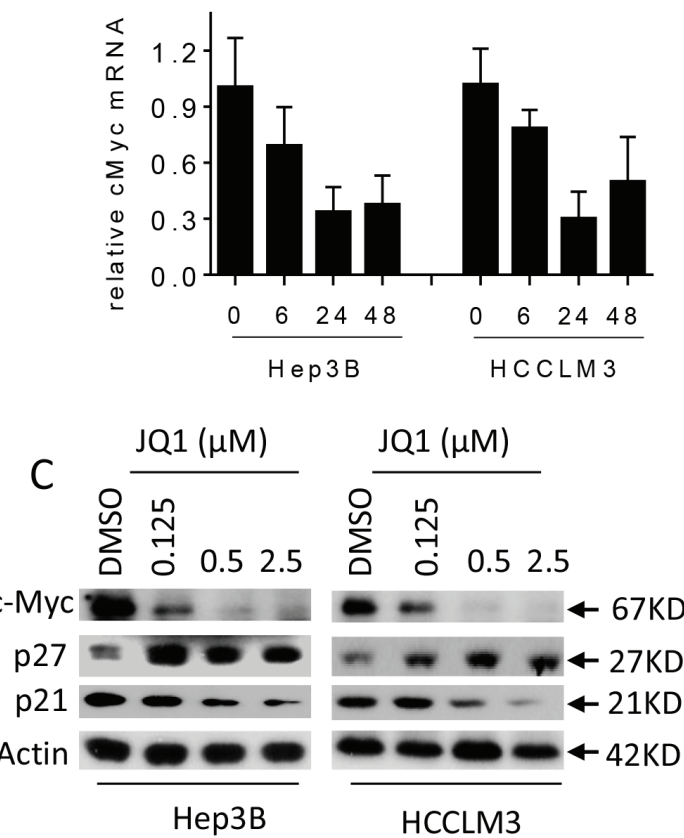

$E$

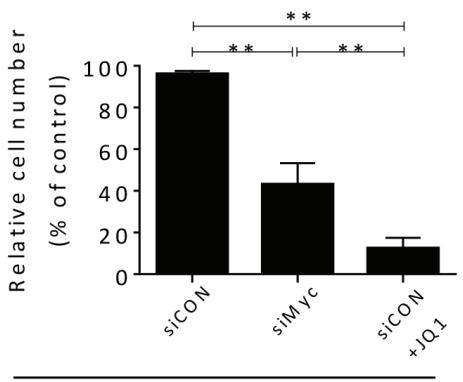

Нер3В
B
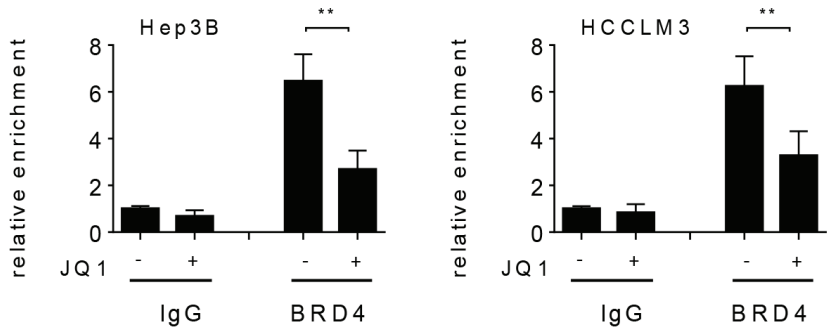

D

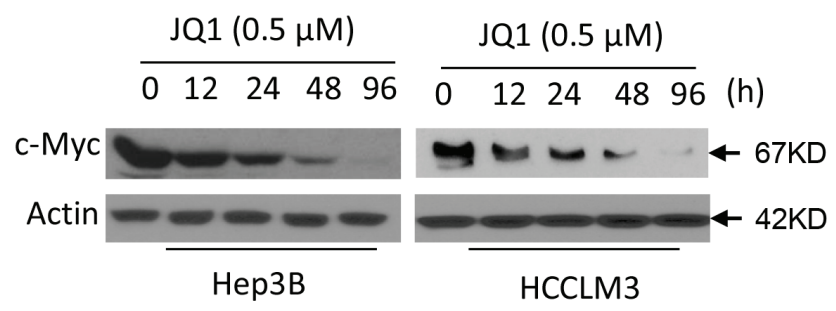

F

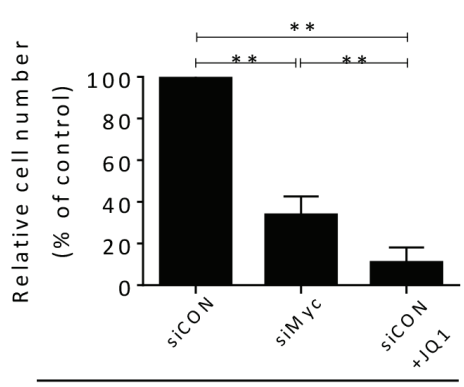

HCCLM3

Figure 4: JQ1 suppresses the expression of c-Myc in HCC cells. A. Hep3B and HCCLM3 cell lines were treated with $0.5 \mu \mathrm{M}$ JQ1 for 6, 24 and 48 h. MYC mRNA expression was analyzed with qRT-PCR. B. Hep3B and HCCLM3 cell lines were treated with $0.5 \mu$ M JQ1 for $24 \mathrm{~h}$. Cells were fixed with formaldehyde and subjected to a ChIP assay using antibodies directed against either an IgG control or BRD4. The results are presented as fold enrichment of MYC at the promoter over the control IgG signal. The errors bars represent the standard deviation of three independent experiments (t-test $* * p<0.01$ ). The enrichment of GAPDH over IgG signal was used as control in Figure S7. C. Hep3B and HCCLM3 cell lines were treated with JQ1 at $0.125,0.5$ and $2.5 \mu \mathrm{M}$ for $48 \mathrm{~h}$. The expression of c-Myc, p27 and p21 was examined by western blotting analysis in whole cell lysates. Actin was used as a loading control. D. Hep3B and HCCLM3 cell lines treated with $0.5 \mu \mathrm{M}$ JQ1 for 12, 24, 48 and $96 \mathrm{~h}$ were harvested for western blot analyses of c-Myc. Actin was used as a loading control. Hep3B E. and HCCLM3 F. cells were transfected with siControl (siCON) or Myc siRNA in absence or presence of $2.5 \mu \mathrm{M}$ JQ1 for $96 \mathrm{~h}$. The relative cell number was manually determined in each condition ( $\mathrm{t}$-test, ${ }^{* *} p<0.01$ ). 
5B). Western blots validated that de-repression of BIM results in a dramatic increase in BIM protein levels in both HCC cell lines (Figure 5C and 5D). siRNA knockdown of BRD4 also increased BIM transcription, suggesting that JQ1 enhances BIM expression through inhibition of BRD4 (Figure S3).

Because BIM is a potent pro-apoptotic BCL-2 protein that binds to and antagonizes several key antiapoptotic family members $[25,26]$, we hypothesized that BIM is involved in JQ1-induced apoptosis. siRNA knockdown of BIM reduced JQ1-induced cell death by $50 \%$ in HCC cell lines (Figure 5E and Figure S6). Moreover, BIM knockdown attenuated JQ1-induced caspase-3 activation and PARP cleavage (Figure 5F), suggesting that BIM is required for JQ1-triggered apoptosis in HCC cells.

\section{JQ1 inhibits tumor growth in HCC mouse models}

To investigate the anti-tumor effects of JQ1 in vivo, we employed HCCLM3 and Hep3B HCC xenograft models. HCC cells were injected subcutaneously into the flanks of nude mice, and, after palpable xenograft tumors were established, the mice were randomly assigned into treatment or control groups. For the treatment groups, JQ1 was administered intra-peritoneally to mice twice daily at $50 \mathrm{mg} / \mathrm{kg}$ body weight for a total of 14 days. The average
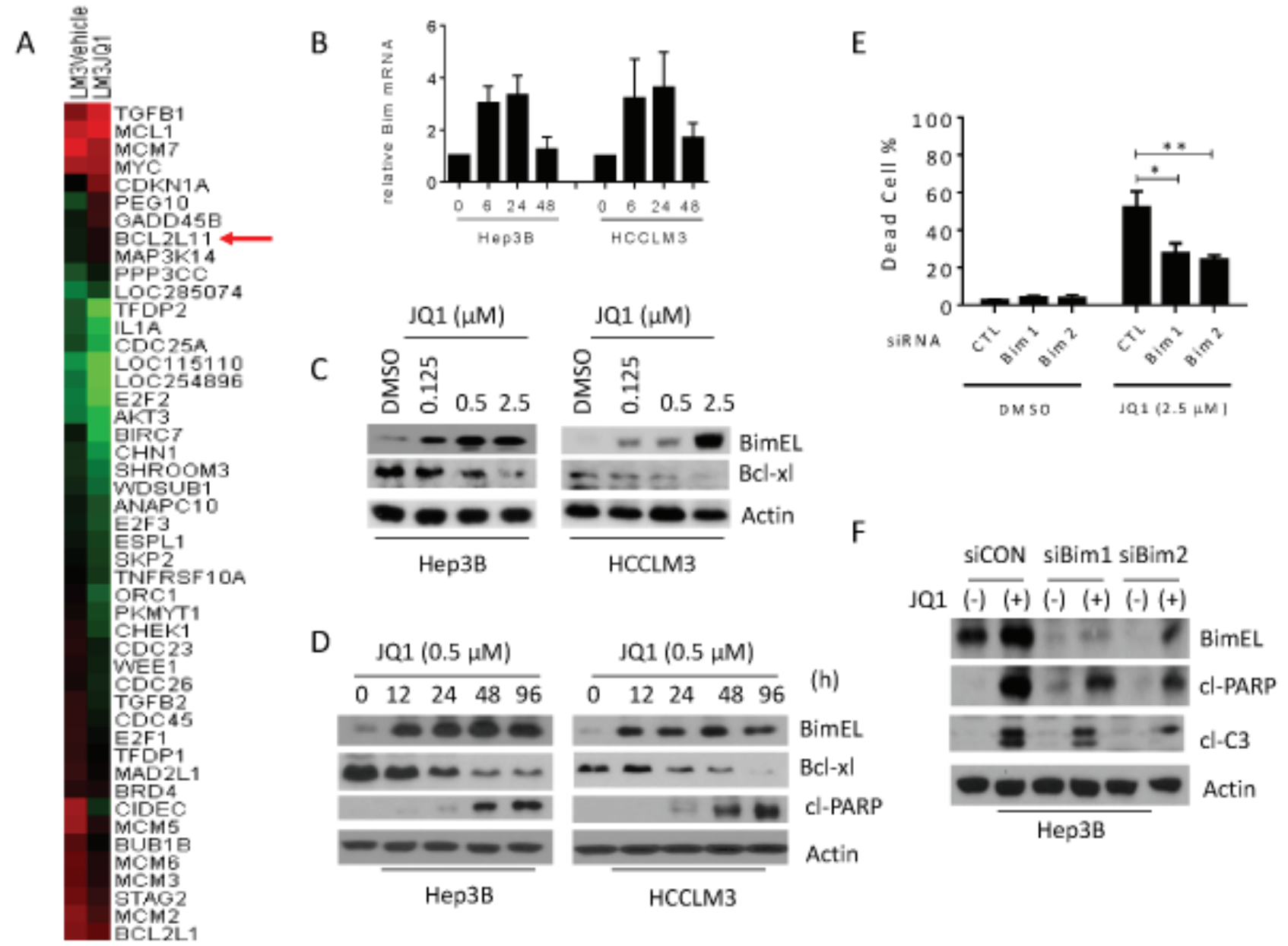

Figure 5: JQ1-induced anti-cancer activity requires Bim up-regulation in HCC cells. A. HCCLM3 cells were treated with $0.5 \mu \mathrm{M}$ JQ1 or DMSO control for $4 \mathrm{~h}$. JQ1-induced changes in global gene expression were examined by RNA-Seq analysis. A heat map depicting the top 46 inhibited or increased $(\mathrm{p} \leq 0.01$ and fold change $\geq 1.5 \log 2)$ genes display enrichment for genes involved in regulation of cell cycle and apoptosis. B. Hep3B and HCCLM3 cell lines were treated with $0.5 \mu \mathrm{M}$ JQ1 for 6,24 and $48 \mathrm{~h}$. BIMEL mRNA expression was analyzed using qRT-PCR. C. Hep3B and HCCLM3 cell lines were treated with JQ1 at $0.125,0.5$ and $2.5 \mu \mathrm{M}$ for $48 \mathrm{~h}$. The expression of BIMEL was examined by western blotting analysis of whole cell lysates. Actin was used as a loading control. D. Hep3B and HCCLM3 cell lines were treated with $0.5 \mu \mathrm{M}$ JQ1 for 12, 24, 48 and $96 \mathrm{~h}$, and the cells were harvested for western blot analysis of BimEL and cleaved PARP (cl-PARP). Actin was used as a loading control. E., F. Hep3B cell line was transfected with control siRNA or Bim siRNA (Bim1 and Bim2) for $24 \mathrm{~h}$. Transfected cells were treated with $2.5 \mu \mathrm{M}$ JQ1 for another $72 \mathrm{~h}$, E. cell death was examined with trypan blue exclusion assays (t-test, ${ }^{*} p<0.05$ ). F. The expression of BimEL, cleaved PARP (cl-PARP) and cleaved Caspase-3 (cl-C3) was examined with western blotting analysis. Actin was used as a loading control. 
tumor volumes in the JQ1-treated groups were smaller than those in the vehicle groups on day 14 in both models (Hep3B, $p<0.05$, HCCLM3, $p<0.05$; Figure 6A and $6 \mathrm{~B})$. Moreover, analysis by two-way ANOVA revealed that JQ1 treatment delayed HCC xenograft growth in the Hep3B model $(p<0.05$; Figure 6C). Mice treated with JQ1 showed no obvious signs of toxicity (based on body weight, food and water intake, activity and general examination) during treatment.

JQ1 treated and untreated tumor tissues from the Hep3B xenograft model were analyzed by western blots and IHC. Treatment with JQ1 at $50 \mathrm{mg} / \mathrm{kg}$ twice per day for 3 days led to BIM accumulation, PARP cleavage, and caspase-3 activation, suggesting the activation of apoptotic signaling in tumor tissues (Figure 6D). JQ1 treatment also inhibited c-Myc and Ki-67 expression in HCC tumor tissues (Figure 6E). Together, these data suggest that JQ1 promotes anti-tumor activity in vivo by inhibiting cell cycle regulators and activating pro-apoptotic signaling pathways.
A

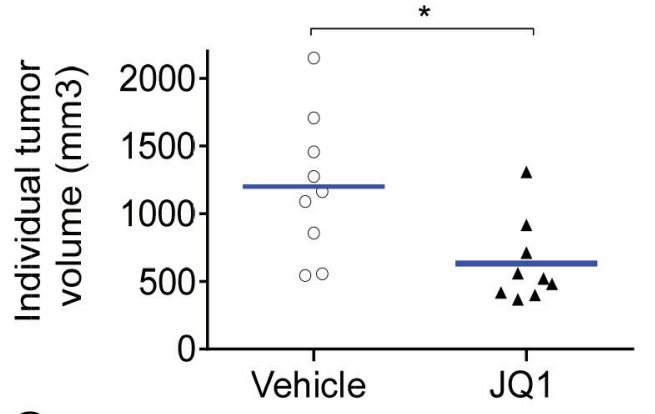

C
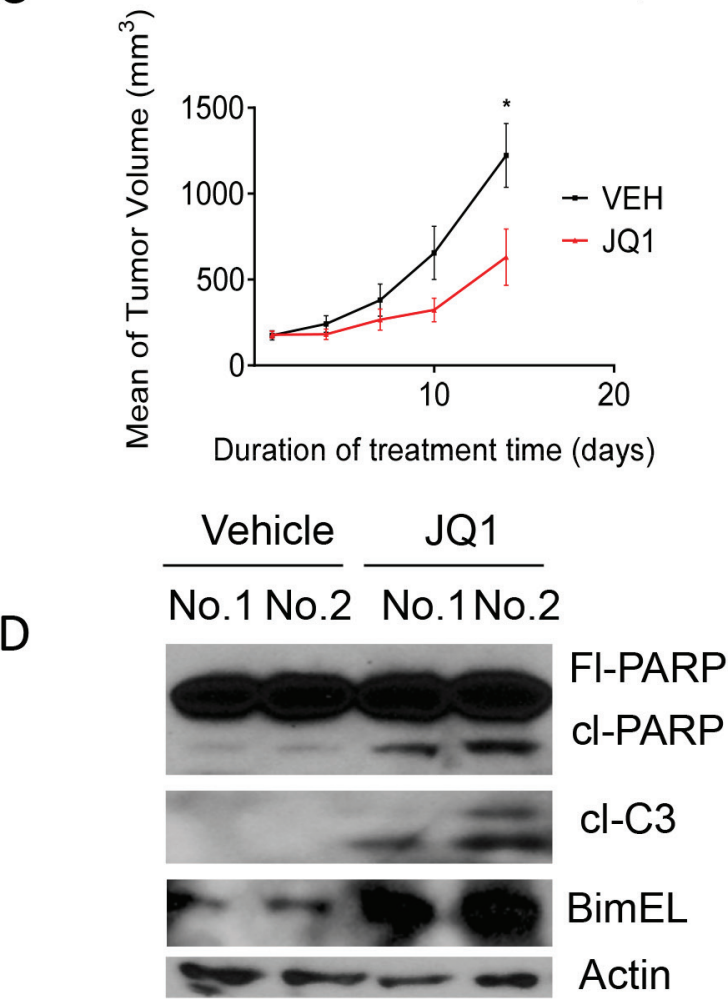

B

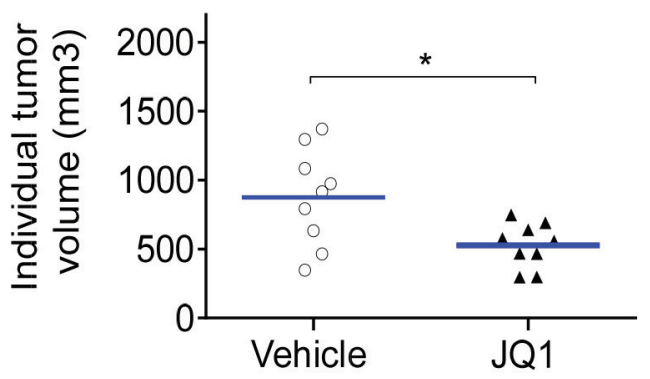

E

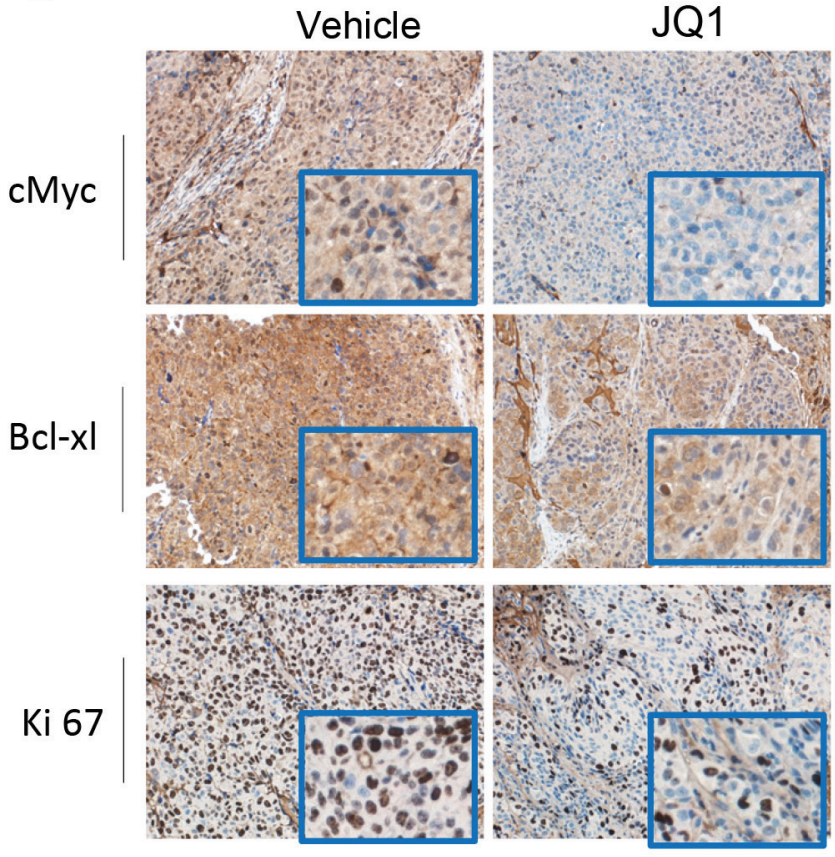

Figure 6: JQ1 inhibits tumor growth in subcutaneous HCC models. A.-C. Hep3B and HCCLM3 cell lines were implanted subcutaneously in mice and allowed to grow until the tumors reached a size of approximately $150 \mathrm{~mm} 3$. Xenografted mice were randomized and treated with JQ1 at $50 \mathrm{mg} / \mathrm{kg}$ i.p. or vehicle twice daily (BID) 5 times a week for 2 weeks. Tumor volume was monitored during the treatments. A. The graph shows changes in the volume of Hep3B tumors. The data are the mean \pm SE $(n=9)$. Tumor volumes from two groups were analyzed by two-way ANOVA analysis $(* * p<0.05)$. B. The graph shows individual tumor volume of Hep3B tumors $(\mathrm{t}-\mathrm{test}$, $* p<0.05$ ). C. The graph shows individual tumor volume of HCCLM3 tumors (t-test, $* p<0.05$ ). D.-E. Hep3B tumors were excised and harvested from animals treated with JQ1 at $50 \mathrm{mg} / \mathrm{kg}$ i.p. BID or vehicle for 3 days. D. The levels of BIMEL, fl-PARP, cl-PARP, and cl-C3 in tissue lysates were examined with western blotting analysis. Actin was used as a loading control. E. The expression of c-Myc and Ki 67 in HCC xenograft tissues was examined by IHC analyses. Representative images are shown for vehicle and treated tumors. 


\section{DISCUSSION}

In the present study, we found that BRD4 expression was increased in HCC cell lines and tumor tissue and correlated with $\mathrm{HCC}$ disease progression. Moreover, we showed that suppression of BRD4 using siRNAs inhibited HCC cell growth. These data suggest a role for BRD4 in HCC development and survival and are in agreement with recent results by Zhang et al, which showed that forced expression of BRD4 promotes cell growth, while shRNAinduced suppression of BRD4 inhibits HCC cell growth [23]. We further showed that JQ1 arrested cell cycle progression at G1 phase, induced apoptosis, and inhibited clonogenic survival and growth at low concentration ranges in $\mathrm{HCC}$ cell lines and patient-derived primary HCC cells. Finally, using mouse HCC xenograft tumor models, we showed that 2 weeks of treatment with JQ1 inhibited tumor growth by suppressing proliferation and inducing apoptosis without severe toxicity. These data suggest that inhibition of BRD4 with small molecule inhibitors such as JQ1 represents a novel strategy for the treatment of HCC.

We also elucidated the mechanism by which JQ1 blocks cell cycle progression in $\mathrm{HCC}$ cells and observed that JQ1 treatment increased p27 expression in HCC cells. Because p27 represents a key downstream mediator of c-Myc-induced regulation of cell proliferation [24, 27], our findings suggest that the JQ1-induced cell cycle arrest may rely on a BRD4-c-Myc-p27 axis in HCC cells. Surprisingly, we found that JQ1 treatment reduced p21 levels in HCC cells, which is in contrast to previous reports that JQ1 arrests the cell cycle at the G1 phase by upregulation of p21 in non-small cell lung cancer, glioblastoma, MM cells, and acute myeloid leukemia cells $[10,11,24-30]$. It is also important to note that the inhibitory effects of JQ1 on c-Myc transcription appeared somewhat delayed in HCC cells compared with kinetics previously observed in MM cells [22]. This suggests regulation of gene transcription by BRD4 is cell typedependent

Our analysis of the mechanisms underlying apoptosis revealed that the mitochondrial apoptosis pathway is involved in JQ1-induced anti-HCC effects. This conclusion is supported by western blot analysis, which showed that JQ1 induces PARP cleavage, caspase-3 activation, and cytosolic cytochrome c release in HCC cells. Mitochondrial apoptosis is promoted by the proapoptotic BCL-2 family of proteins [31]. In this study, we unexpectedly observed that JQ1 treatment led to rapid and dramatic BIM up-regulation at both the mRNA and protein level in HCC cells. Moreover, our data show that BIM suppression rescues HCC cells from JQ1-induced apoptotic cell death, suggesting an essential role for BIM in the anti-HCC effects of JQ1.

Recently, other groups have reported that BET inhibition leads to upregulation of BIM. Using a malignant peripheral nerve sheath tumors (MPNSTs) mouse model, Patel and colleagues showed that suppression of BRD4 with either JQ1 or siRNA rapidly increases BIM expression in MPNSTs cells and, similar to the results presented here, BIM knockdown inhibits JQ1-induced apoptosis [26]. In addition, Gallagher and colleagues showed that BIM is required for the induction of apoptosis by the BET protein inhibitor I-BET151 in melanoma cells [25]. Together, these studies underscore the importance of $\mathrm{BIM}$ in the induction of apoptosis resulting from BRD4 (BET) inhibition. As BRD4 regulates gene expression through the recruitment of the $\mathrm{P}-\mathrm{TEFb}$, it remains to be determined how JQ1 inhibition of BRD4 de-represses BIM expression. Moreover, because JQ1 also inhibits BRD2, BRD3, and other BET family members, in the future it will be important to test the extent to which BET family members contribute to JQ1 anti-tumor activity in HCC and other cancers $[4,32]$.

Our finding that BRD4 expression is elevated in a fraction of adjacent non-tumor liver tissue, albeit to a lesser extent than in tumor tissue, raises a potential concern for the future clinical utility of BRD4 inhibitors in human $\mathrm{HCC}$, as improper drug use may cause liver damage. In addition, although JQ1 stimulated anti-HCC activity in vitro, treatment with JQ1 at $50 \mathrm{mg} / \mathrm{kg}$ twice daily in vivo had only a modest effect on tumor growth, suggesting that BRD4 inhibitors with increased bioavailability or potency may be required for improved therapeutic responses [33].

\section{MATERIALS AND METHODS}

\section{Cell lines and compound preparation}

The HCC cell lines Hep3B, HCCLM3, HuH7, HepG2, MHCC97H, SMMC7721 and BEL7402 were obtained from the China Center for Type Culture Collection (Wuhan, China) and maintained in highglucose DMEM (HyClone/Thermo Fisher Scientific, Beijing, China) supplemented with $10 \%$ heat-inactivated fetal bovine serum (Hangzhou Sijiqing Biological Engineering Materials Co., Ltd, Hangzhou, China). JQ1 was kindly gifted by Professor James Bradner (Harvard Medical School). JQ1 was dissolved in Dimethyl sulfoxide (DMSO) at a stock concentration of $10 \mathrm{mmol} / \mathrm{L}$ and stored at $-20^{\circ} \mathrm{C}$.

\section{MTT cell viability assay}

Cell viability was measured using a 3-[4,5-dimethylthiazol-2-thiazolyl]-2,5-diphenyltetrazolium bromide (MTT) assay that is based on mitochondrial conversion of MTT from a soluble tetrazolium salt into an insoluble colored formazan precipitate, which was dissolved in DMSO and quantified by spectrophotometry (Thermo Multiskan MK3; Thermo 
Labsystems, Shanghai, China) to obtain optical density (OD) values. HCC cells were plated in 96-well culture dishes (Costar, Cambridge, MA, USA) at a density of $1000-2000$ cells/well in $100 \mu \mathrm{L}$ of medium. Serial dilutions were generated from a stock solution of JQ1 to the desired concentrations. All experimental concentrations were replicated in triplicate. Four hours before the desired time points, $10 \mu \mathrm{L}$ of $10 \mathrm{mg} / \mathrm{mL}$ MTT was added. After a $4-\mathrm{h}$ incubation, all media from wells were removed, and 100 $\mu \mathrm{L}$ of DMSO was added. The percentages of absorbance relative to those of untreated control samples were plotted as a function of drug concentration (log scale). Inhibition of cell viability was measured by percentage of viable cells relative to the control: $\%$ inhibition $=100 \% \times$ ODT $/$ ODC, where ODT is the average OD value of the treated samples and ODC is the average OD value of the control samples.

\section{Cell death, flow cytometry, and clonogenic assays}

Cell death was quantified by microscopic examination in trypan blue exclusion assays. Cell cycle analysis was examined by propidium iodide (PI, $50 \mu \mathrm{g}$ / $\mathrm{mL}$ in PBS) and flow cytometry with a BD LSR II system (BD Biosciences, Shanghai, China). For clonogenic assays, 1,000 cells were seeded into 6-well dishes in 5 $\mathrm{mL}$ of medium, treated as indicated, and maintained for 14 days at $37^{\circ} \mathrm{C}$ in a $5 \% \mathrm{CO} 2$ incubator. Cells were then washed with drug-free medium, stained with $0.01 \%(\mathrm{w} / \mathrm{v})$ crystal violet, and cell colonies ( $>50$ cells) were counted at 14 days post-treatment. The assays were performed in duplicate with at least three different repeats per treatment.

\section{Cell fractionation}

HCC cells were treated as indicated, collected, washed with PBS and suspended in 5 volumes of chilled buffer A (250 mM sucrose, $20 \mathrm{mM} \mathrm{HEPES,} 10 \mathrm{mM} \mathrm{KCl}$, $1.5 \mathrm{mM} \mathrm{MgCl} 2,1 \mathrm{mM}$ EDTA, 1 mM EGTA, $1 \mathrm{mM}$ DLdithiothreitol [DTT], $17 \mu \mathrm{g} / \mathrm{mL}$ phenylmethylsulfonyl fluoride [PMSF], $8 \mu \mathrm{g} / \mathrm{mL}$ aprotinin and $2 \mu \mathrm{g} / \mathrm{mL}$ leupeptin [pH 7.4]) on ice for $15 \mathrm{~min}$. Cell fractionation was performed using the homogenization method. Briefly, cells were homogenized using an ice-cold cylinder cell homogenizer (20-25 strokes). Homogenized cell lysates were separated by centrifugation at $750 \mathrm{~g}$ for $10 \mathrm{~min}$, and the supernatants were further centrifuged at 10,000 $\mathrm{g}$ for $20 \mathrm{~min}$. The remaining supernatant was used as the cytosolic fraction and subjected to western blot analysis.

\section{Western blotting}

Cells were lysed using radioimmunoprecipitation (RIPA) assay lysis buffer (PBS containing 1\% NP40, 0.5\%
Na-deoxycholate, and $0.1 \%$ SDS) supplemented with 1 $\mu \mathrm{mol} / \mathrm{L}$ phenylmethylsulfonyl fluoride and 1 protease inhibitor cocktail tablet per $10 \mathrm{~mL}$ on ice for $20 \mathrm{~min}$, and lysates protein concentration were determined using the Bio-Rad protein assay kit according to the manufacturer's instructions. Proteins were electrophoresed onto 4-20\% SDS-PAGE gels (Invitrogen, Carlsbad, CA, USA) and transferred onto polyvinylidene difluoride membranes. Following blocking in 5\% milk, the membranes were incubated with a specific primary antibody, washed, and incubated with horseradish peroxidase-linked secondary antibody (GE Healthcare, Beijing, China). Signals were visualized with chemiluminescent horseradish peroxidase antibody detection reagent (Denville Scientific, Guangzhou, China).

The antibodies used were as follows: BRD4 (H-250) (sc-48772); Caspase-9 (96.1.23)(sc-56076); Caspase-3 (H-277)(sc-7148); c-Myc (9E10)(sc-40); p27 (C-19) (sc-528); p21 (C-19)(sc-397); Mcl-1 (S-19)(sc-819); Bim (H-191) (sc-11425); and Actin (C4)(sc-47778). The antibodies were purchased from Santa Cruz Biotechnology (Shanghai, China).

\section{qRT-PCR}

Total RNA was isolated using TRIzol reagent (Invitrogen), and cDNA was synthesized using the high capacity cDNA archive kit (Applied Biosystems). The mRNA level of $M Y C$ was quantified by qRTPCR using SYBR Premix Ex Taq (Applied Takara Bio, Shanghai, China). The $M Y C$ primers were as follows: 5'-TCTCCACTCACCAGCACAACTACG and 3 '-ATCTGCTTCAGGACCCT. The BIM (BCL2L11) primers were as follows: 5'TAAGTTCTGAGTGTGACCGAGA-3' and 3'- GCTCTGTCTGTAGGGAGGTAGG-5'. The CDKN1A (p21) primers were as follows: 5'- GAGGCCGGGATGAGTTGGGAGGAG-3', 3'-CAGCCGGCGTTTGGAGTGGTAGAA-5.

The $C D K N 1 B$ (p27) primers were as follows: 5-CCGGTGGACCACGAAGAGT-3, and 5-GCTCGCCTCTTCCATGTCTC-3. The GAPDH primers were as follows: 5-TGCCTCCTGCACCACCAACT-3, and 5- CGCCTGCTTCACCACCTTC-3. The PCR conditions included an initial denaturation step of $95^{\circ} \mathrm{C}$ for $2 \mathrm{~min}$, followed by 35 cycles of $95^{\circ} \mathrm{C}$ for $10 \mathrm{~s}, 56^{\circ} \mathrm{C}$ for 20 $\mathrm{s}$, and $72^{\circ} \mathrm{C}$ for $20 \mathrm{~s}$, and a final elongation step of $72^{\circ} \mathrm{C}$ for $10 \mathrm{~min}$. Quantitation relative to the endogenous control $(G A P D H)$ was performed using the Applied Biosystems 7500 Fast System SDS software.

\section{RNA interference}

Commercially available siRNAs inhibiting BRD4 and BIM were used to knock down the respective 
proteins in HCC cell lines. The siRNA transfections (50 pmol/L) were performed using Lipofectamine RNAiMax transfection reagent (Invitrogen, Shanghai, China). Nonsilencing siRNAs (siCON) and validated BRD4 siRNAs (siBRD4-1) were purchased from Qiagen. BRD4 siRNA (siBRD4-2) (sc-43639) and BIM siRNA (siBim-1) (sc29802) were purchased from (Santa Cruz Biotechnology), the second BIM siRNA (siBim2) (6461) was purchased from Cell Signaling Technology (Shanghai, China), and c-Myc siRNA (siMYC) were purchased from (GE Dharmacon, Shanghai, China).

\section{Chromatin-immunoprecipitation (ChIP)}

ChIP experiments were conducted as described previously (13). Briefly, prior to harvesting, sodium butyrate (Sigma-Aldrich) was added to the cell culture medium to a final concentration of $20 \mathrm{mM}$ and mixed gently. The cells were then harvested by trypsinization and cross-linked with $1 \%(\mathrm{v} / \mathrm{v})$ formaldehyde for $10 \mathrm{~min}$ at room temperature. The cross-linking reaction was terminated by adding glycine to a final concentration of $125 \mathrm{mM}$ for $5 \mathrm{~min}$. Cells were then lysed with lysis buffer (50 mM Tris-HCl, $10 \mathrm{mM}$ EDTA, 1\% SDS, protease inhibitor cocktail and $20 \mathrm{mM}$ sodium butyrate). The chromatin was sheared by sonication to a DNA fragment size of $200-600 \mathrm{bp}$ and precipitated by centrifugation at $12000 \times \mathrm{g}$ at $4^{\circ} \mathrm{C}$ for $10 \mathrm{~min}$. For immunoprecipitations, $5 \mu \mathrm{g}$ of BRD4 antibody (Cell Signaling Technology, \#13440) or of a rabbit immunoglobulin G (IgG) (Cell Signaling Technology, \#2729) control were incubated overnight with the sheared DNA. The next day, $50 \mu \mathrm{L}$ of protein G Dynabeads (Life Technologies) were added and incubated for $4 \mathrm{~h}$ at $4^{\circ} \mathrm{C}$. The antibody/chromatin/ beads complexes were washed four times with RIPA buffer (10 mM Tris-HCl, $1 \mathrm{mM}$ EDTA, $0.5 \mathrm{mM}$ EGTA, $1 \%$ Triton-X100, 0,1\% SDS, 0,1\% sodium-deoxycholate and $140 \mathrm{mM} \mathrm{NaCl}$ ) and once with TE buffer $(10 \mathrm{mM}$ Tris$\mathrm{HCl}, 10 \mathrm{mM}$ EDTA). DNA was incubated with elution buffer $(20 \mathrm{mM}$ Tris- $\mathrm{HCl}, 5 \mathrm{mM}$ EDTA, $20 \mathrm{mM}$ sodium butyrate, $50 \mathrm{mM} \mathrm{NaCl}$ ) containing $50 \mu \mathrm{g} / \mathrm{mL}$ proteinase $\mathrm{K}$ at $68^{\circ} \mathrm{C}$ for $2 \mathrm{~h}$. DNA was purified using the Qiagen MinElute columns (Qiagen). For all reactions, 300 pg of ChIP and input DNA were analyzed using qPCR with the following primers $(4,5): M Y C$ promoters (forward) 5'-TCACGTTTGCCATTACCGGTTC-'3 and (reverse) 5'-TTTCAGGTTGGCTGCA G A AGGT-3'. Promoters for GAPDH: 5-TGCCTCCTGCACCACCAACT-3, and 5- CGCCTGCTTCACCACCTTC-3. were used to rule out non-specific binding (Figure S7).

\section{Primary HCC cell isolation, culture and treatment}

Fresh HCC tissues were obtained from the surgical specimens at the Department of Hepatobiliary and Pancreatic Surgery of the First Affiliated Hospital of Zhengzhou University as described previously [34]. Written informed consent was obtained from each patient, and the study was approved by the Ethics Committee of the First Affiliated Hospital of Zhengzhou University based on the ethical guidelines of the 1975 Declaration of Helsinki.

\section{Immunohistochemistry (IHC)}

A tissue microarray was obtained from Shanghai Outdo Biotech Co., Ltd (Shanghai, China). Normal liver tissue sections were obtained from the Pathology Department of the First Affiliated Hospital of Zhengzhou University with patient consent. Tumor tissues were obtained from tumor-bearing mice treated with JQ1 or vehicle control for 3 days. The antibodies used for IHC were from the following companies: BRD4 (HPA015055) from Sigma (Shanghai, China); c-MYC (AF3696) from R\&D systems (Shanghai, China); and Ki 67 (550609) from BD Biosciences (Shanghai, China). IHC was performed as described previously [6]. Briefly, the sections were de-paraffinized by xylene, rehydrated in graded concentrations of ethanol and boiled in antigen retrieval buffer (Abcam, Shanghai, China) in a microwave oven for $5 \mathrm{~min}$. Slides of consecutive sections were incubated with diluted antibodies at room temperature for $2 \mathrm{~h}$. After incubation, the slides were washed three times with PBS, incubated with horseradish peroxidase (HRP)-conjugated antibody (Invitrogen, Shanghai, USA) at room temperature for $30 \mathrm{~min}$, followed by incubation of $\mathrm{ABC}$ (avidin-biotin complex, Vectorlabs, Shanghai, China) for $30 \mathrm{~min}$ and visualization by the addition of 3,3'-diaminobenzidine tetrahydrochloride (DAB) reagent (Dako Diagnostics (Shanghai) Co., Ltd.), with hematoxylin as the counter stain. Images of stained slides were captured using a standard light microscope.

\section{Animal studies}

All experimental procedures were performed in accordance with protocols approved by the Institutional Laboratory Animal Care and Use Committee of Zhengzhou University. All animals received humane care according to the criteria outlined in the "Guide for the Care and Use of Laboratory Animals Chinese Version" (2006). HCC Hep3B and HCCLM3 cells (5 x 106 cells) suspended in $0.1 \mathrm{~mL}$ of Matrigel were implanted subcutaneously into the flank of 5-week-old athymic nude mice (Hunan Slack King of laboratory animals, Changsha, China). Once tumors had reached a minimal volume of $100 \mathrm{~mm} 3$, the mice were randomly assigned to the control or treated groups (nine to 10 mice per group). Tumorbearing mice were treated twice (BID) per day with JQ1, $50 \mathrm{mg} / \mathrm{kg}$, i.p. or an equal amount vehicle as a control for 
2 weeks. Tumor volumes were evaluated twice weekly by measuring two perpendicular diameters with calipers. Tumor volume $(\mathrm{V})$ was calculated using the following equation: $\mathrm{V}=(\mathrm{a} 2 \mathrm{xb})$, where $\mathrm{a}$ is the width of the tumor (small diameter) and $\mathrm{b}$ the length (large diameter) in millimeters. To investigate the mechanism of JQ1-induced anti-tumor activity, tumor-bearing mice were treated twice per day with JQ1, $50 \mathrm{mg} / \mathrm{kg}$, i.p, or vehicle for 3 days. Then, the mice were sacrificed, and tumor tissues were harvested and either fixed in formalin for IHC staining for c-MYC and Ki 67 or lysed and examined for PARP cleavage and caspase-3 activation.

\section{RNA-Seq}

Cells were treated with JQ1 or the corresponding DMSO control for $4 \mathrm{~h}$. RNA-Seq expression analysis was performed by BGI-Tech Company (Shenzhen, China). Complete results are reported in Supplementary File 1 (http://www.ncbi.nlm.nih.gov/bioproject/281518, PRJNA281518).

\section{Statistical analyses}

All data are displayed as the mean \pm SEM unless specified otherwise. The types of statistical methods that were used to evaluate statistical significance $(p<0.05$ was deemed significant) are indicated in the text and/or figure legends.

\section{ACKNOWLEDGMENTS}

The authors thank Dr. James Bradner (Harvard Medical School) for his generosity in providing JQ1.

\section{CONFLICTS OF INTEREST}

The authors declare no conflict of interest.

\section{REFERENCES}

1. Abou-Alfa GK, Schwartz L, Ricci S, Amadori D, Santoro A, Figer A, De Greve J, Douillard JY, Lathia C, Schwartz B, Taylor I, Moscovici M and Saltz LB. Phase II study of sorafenib in patients with advanced hepatocellular carcinoma. Journal of clinical oncology : official journal of the American Society of Clinical Oncology. 2006; 24(26):4293-4300.

2. Mujtaba S, Zeng L and Zhou MM. Structure and acetyllysine recognition of the bromodomain. Oncogene. 2007; 26(37):5521-5527.

3. Filippakopoulos P, Qi J, Picaud S, Shen Y, Smith WB, Fedorov O, Morse EM, Keates T, Hickman TT, Felletar I, Philpott M, Munro S, McKeown MR, Wang Y, Christie AL,
West N, et al. Selective inhibition of BET bromodomains. Nature. 2010; 468(7327):1067-1073.

4. Zuber J, Shi J, Wang E, Rappaport AR, Herrmann H, Sison EA, Magoon D, Qi J, Blatt K, Wunderlich M, Taylor MJ, Johns C, Chicas A, Mulloy JC, Kogan SC, Brown P, et al. RNAi screen identifies Brd4 as a therapeutic target in acute myeloid leukaemia. Nature. 2011; 478(7370):524-528.

5. Delmore JE, Issa GC, Lemieux ME, Rahl PB, Shi JW, Jacobs HM, Kastritis E, Gilpatrick T, Paranal RM, Qi J, Chesi M, Schinzel AC, McKeown MR, Heffernan TP, Vakoc CR, Bergsagel PL, et al. BET Bromodomain Inhibition as a Therapeutic Strategy to Target c-Myc. Cell. 2011; 146(6):903-916.

6. Dawson MA, Kouzarides T and Huntly BJP. Targeting Epigenetic Readers in Cancer. New England Journal of Medicine. 2012; 367(7):647-657.

7. Loosveld M, Castellano R, Gon S, Goubard A, Crouzet T, Pouyet L, Prebet T, Vey N, Nadel B, Collette Y and PayetBornet D. Therapeutic Targeting of c-Myc in T-Cell Acute Lymphoblastic Leukemia (T-ALL). Oncotarget. 2014; 5(10):3168-3172. doi: 10.18632/oncotarget.1873.

8. Herrmann H, Blatt K, Shi JW, Gleixner KV, Cerny-Reiterer S, Mullauer L, Vakoc CR, Sperr WR, Horny HP, Bradner JE, Zuber J and Valent P. Small-molecule inhibition of BRD4 as a new potent approach to eliminate leukemic stem-and progenitor cells in acute myeloid leukemia (AML). Oncotarget. 2012; 3(12):1588-1599. doi: 10.18632/ oncotarget.733.

9. Henssen A, Thor T, Odersky A, Heukamp L, El-Hindy N, Beckers A, Speleman F, Althoff K, Schäfers S and Schramm A. BET bromodomain protein inhibition is a therapeutic option for medulloblastoma. Oncotarget. 2013; 4(11):2080. doi: 10.18632/oncotarget.1534.

10. Shimamura T, Chen Z, Soucheray M, Carretero J, Kikuchi E, Tchaicha JH, Gao YD, Cheng KA, Cohoon TJ, Qi J, Akbay E, Kimmelman AC, Kung AL, Bradner JE and Wong KK. Efficacy of BET Bromodomain Inhibition in Kras-Mutant Non-Small Cell Lung Cancer. Clinical cancer research. 2013; 19(22):6183-6192.

11. Chapuy B, McKeown MR, Lin CY, Monti S, Roemer MGM, Qi J, Rahl PB, Sun HH, Yeda KT, Doench JG, Reichert E, Kung AL, Rodig SJ, Young RA, Shipp MA and Bradner JE. Discovery and Characterization of SuperEnhancer-Associated Dependencies in Diffuse Large B Cell Lymphoma (vol 24, pg 777, 2013). Cancer cell. 2014; 25(4):545-546.

12. Qiu HF, Jackson AL, Kilgore JE, Zhong Y, Chang LLY, Gehrig PA, Zhou CX and Bae-Jump VL. JQ1 suppresses tumor growth through downregulating LDHA in ovarian cancer. Oncotarget. 2015; 6(9):6915-6930. doi: 10.18632/ oncotarget.3126.

13. Asangani IA, Dommeti VL, Wang X, Malik R, Cieslik M, Yang R, Escara-Wilke J, Wilder-Romans K, Dhanireddy S and Engelke C. Therapeutic targeting of BET bromodomain proteins in castration-resistant prostate cancer. Nature. 
2014; 510(7504):278-282.

14. Park IY, Sohn BH, Yu E, Suh DJ, Chung YH, Lee JH, Surzycki SJ and Lee YIK. Aberrant epigenetic modifications in-hepatocarcinogenesis induced by hepatitis B virus X protein. Gastroenterology. 2007; 132(4):14761494.

15. Thorgeirsson SS and Grisham JW. Molecular pathogenesis of human hepatocellular carcinoma. Nature genetics. 2002; 31(4):339-346.

16. Shukla SD and Aroor AR. Epigenetic effects of ethanol on liver and gastrointestinal injury. World Journal of Gastroenterology. 2006; 12(33):5265-5271.

17. Farazi PA and DePinho RA. Hepatocellular carcinoma pathogenesis: from genes to environment. Nature Reviews Cancer. 2006; 6(9):674-687.

18. Schlaeger C, Longerich $\mathrm{T}$, Schiller C, Bewerunge $\mathrm{P}$, Mehrabi A, Toedt G, Kleeff J, Ehemann V, Eils R, Lichter P, Schirtnacher P and Radwimmer B. Etiology-dependent molecular mechanisms in human hepatocarcinogenesis. Hepatology. 2008; 47(2):511-520.

19. Lin C-P, Liu C-R, Lee C-N, Chan T-S and Liu HE. Targeting c-Myc as a novel approach for hepatocellular carcinoma. World journal of hepatology. 2010; 2(1):16.

20. Kawate S, Fukusato T, Ohwada S, Watanuki A and Morishita Y. Amplification of c-myc in hepatocellular carcinoma: correlation with clinicopathologic features, proliferative activity and p53 overexpression. Oncology. 1999; 57(2):157-163.

21. Puissant A, Frumm SM, Alexe G, Bassil CF, Qi J, Chanthery YH, Nekritz EA, Zeid R, Gustafson WC, Greninger P, Garnett MJ, McDermott U, Benes CH, Kung AL, Weiss WA, Bradner JE, et al. Targeting MYCN in neuroblastoma by BET bromodomain inhibition. Cancer Discov. 2013; 3(3):308-323.

22. Loven J, Hoke HA, Lin CY, Lau A, Orlando DA, Vakoc CR, Bradner JE, Lee TI and Young RA. Selective inhibition of tumor oncogenes by disruption of super-enhancers. Cell. 2013; 153(2):320-334.

23. Zhang P, Dong Z, Cai J, Zhang C, Shen Z, Ke A, Gao D, Fan J and Shi G. BRD4 promotes tumor growth and epithelial-mesenchymal transition in hepatocellular carcinoma. Int J Immunopathol Pharmacol. 2015; 28(1):3644.

24. Rodriguez A, Jung EJ, Yin Q, Cayrol C and Flemington EK. Role of c-myc regulation in Zta-mediated induction of the cyclin-dependent kinase inhibitors p21 and p27 and cell growth arrest. Virology. 2001; 284(2):159-169.

25. Gallagher SJ, Mijatov B, Gunatilake D, Tiffen JC, Gowrishankar K, Jin L, Pupo GM, Cullinane C, Prinjha RK, Smithers N, McArthur GA, Rizos H and Hersey P. The epigenetic regulator I-BET151 induces BIM-dependent apoptosis and cell cycle arrest of human melanoma cells. The Journal of investigative dermatology. 2014; 134(11):2795-2805.
26. Patel AJ, Liao C-P, Chen Z, Liu C, Wang Y and Le LQ. BET bromodomain inhibition triggers apoptosis of NF1associated malignant peripheral nerve sheath tumors through Bim induction. Cell Reports. 2014; 6(1):81-92.

27. Yang W, Shen J, Wu M, Arsura M, FitzGerald M, Suldan Z, Kim DW, Hofmann CS, Pianetti S and Romieu-Mourez R. Repression of transcription of the $\mathrm{p} 27$ Kip 1 cyclindependent kinase inhibitor gene by c-Myc. Oncogene. 2001; 20(14):1688-1702.

28. Albrecht JH, Poon RY, Ahonen CL, Rieland BM, Deng $\mathrm{C}$ and Crary GS. Involvement of p21 and p27 in the regulation of CDK activity and cell cycle progression in the regenerating liver. Oncogene. 1998; 16(16):2141-2150.

29. Mertz JA, Conery AR, Bryant BM, Sandy P, Balasubramanian S, Mele DA, Bergeron L and Sims RJ. Targeting MYC dependence in cancer by inhibiting BET bromodomains. Proceedings of the National Academy of Sciences of the United States of America. 2011; 108(40):16669-16674.

30. Cheng ZX, Gong YY, Ma YF, Lu KH, Lu X, Pierce LA, Thompson RC, Muller S, Knapp S and Wang JL. Inhibition of BET Bromodomain Targets Genetically Diverse Glioblastoma. Clinical cancer research. 2013; 19(7):17481759.

31. Zhang SJ, Li GQ, Ma XX, Wang Y, Liu GZ, Feng LS, Zhao YF, Zhang G, Wu Y, Ye XX, Qin BM and Lu JF. Norcantharidin enhances ABT-737-induced apoptosis in hepatocellular carcinoma cells by transcriptional repression of Mcl-1. Cellular signalling. 2012; 24(9):1803-1809.

32. Coude MM, Braun T, Berrou J, Dupont M, Bertrand S, Masse A, Raffoux E, Itzykson R, Delord M, Riveiro ME, Herait P, Baruchel A, Dombret H and Gardin C. BET inhibitor OTX015 targets BRD2 and BRD4 and decreases c-MYC in acute leukemia cells. Oncotarget. 2015; 6(19):17698-17712. doi:10.18632/oncotarget.4131.

33. Trabucco SE, Gerstein RM, Evens AM, Bradner JE, Shultz LD, Greiner DL and Zhang H. Inhibition of Bromodomain Proteins for the Treatment of Human Diffuse Large B- cell Lymphoma. Clinical cancer research. 2015; 21(1):113-122.

34. Zhang S, Li G, Zhao Y, Liu G, Wang Y, Ma X, Li D, Wu $\mathrm{Y}$ and $\mathrm{Lu}$ J. Smac mimetic SM-164 potentiates APO2L/ TRAIL- and doxorubicin-mediated anticancer activity in human hepatocellular carcinoma cells. PLoS ONE. 2012; 7(12):e51461. 